\title{
Abstrak \\ PENYELESAIAN KEJAHATAN TERHADAP KEMANUSIAAN DALAM PERSPEKTIF HAK ASASI MANUSIA
}

\author{
Subekti ${ }^{1}$ \\ Dudik Djaja Sidarta ${ }^{2}$
}

Kebijakan pemerintah dalam menyelesaikan kejahatan HAM berat yang terjadi di masa demokrasi otoriter akan diselesaikan berdasarkan Undang-Undang Nomor 39 Tahun 1999 Tentang Hak Asasi Manusia dan Undang-Undang Nomor 26 Tahun 2000 tentang Peradilan Hak Asasi Manusia . Kedua undang-undang tersebut menganut asas retroaktif. Mulai tahun 2000 sampai tahun 2004 telah terjadi empat kali perubahan Undang-Undang Dasar 1945. Dalam UUD 1945 perubahan sesuai dengan Pasal 28I tidak menganut asas retroaktif, artinya konstitusi ini melarang hukum berlaku surut. Kebijakan pemerintah ini menjadi persoalan, karena telah terjadi kontradiktif sehingga menimbulkan masalah yaitu bagaimana kebijakan pemerintah yang kontradiktif ini dalam menyelesaiakan pelanggaran HAM berat yang terjadi di masa lalu?

Tujuan penelitian ini adalah menjawab dan menganalisis kebijakan pemerintah yang kontradiktif dalam menyelesaikan kasus pelanggaran HAM berat yang yang terjadi di masa lalu, diselesaikan oleh undang-undang HAM yang baru ditinjau dari aspek kemanusian dan hukum. Penelitian ini dapat memberikan kontribusi bagi pengembangan ilmu hukum dan humaniora, memberikan referensi dan sebagai bahan pertimbangan bagi pembentuk undangundang dan aparat penegak hukum dalam menerapkan sebuah kebijakan yang berkenaan dengan penyelesaian kejahatan terhadap kemanusiaan.

Dalam menjawab permasalahan di atas peneliti menggunakan metode penelitian normatif, yaitu menggunakan bahan hukum primer dan bahan sekunder untuk menjawab permasalahan di atas. Pendekatan yang digunakan adalah pendekatankonseptual (conceptual approach), pendekatanperaturanperundang-undangan (statute approach) dan pendekatan kasus (case approach).

Hasil penelitian adalah bahwa kebijakan dalam menyelesaikan pelanggaran HAM berat di masa lalu merupakan kebijakan yang kontradiktif, dimana asas retroaktif diterapkan, dibentuk pengadilan HAM ad Hoc tetapi aturan hukum yang diterapkan atau sanksi yang dijatuhkan menggunakan aturan KUHP yang merupakan pelanggaran HAM biasa/umum (ordinary crime).

Kata Kunci : Pelanggaran HAM Berat, Kebijakan, Kejahatan Kemanusiaan

\footnotetext{
${ }^{1}$ Dosen Fakultas Hukum Universitas Dr. Soetomo (UNITOMO) Surabaya, Subekti@Unitomo.ac.id

${ }^{2}$ Dosen Fakultas Hukum Universitas Dr. Soetomo (UNITOMO) Surabaya, dudik.djaja@unitomo.ac.id
} 


\section{PENDAHULUAN}

Pemerintah pada masa reformasi telah mengeluarkan Undang-Undang Republik Indonesia Nomor 39 Tahun 1999 Tentang Hak Asasi dan Undang-Undang Republik Indonesia Nomor 26 Tahun 2000 tentang Pengadilan HAM. Adanya dua undang -undang ini maka perkara pelanggaran HAM berat bisa terselesaikan secaratuntas sebab sudah diatur secara lengkap baik hukum formilnya maupun hukum materiilnya.Pasal 28I (1) UUD NRITahun 1945 menentukan:

Hak untuk hidup, hak untuk tidak disiksa, hak kemerdekaan pikiran dan hati nurani, hak beragama, hak untuk tidak diperbudak, hak untuk diakui sebagai pribadi dihadapan hukum, dan hak untuk tidak dituntut atas dasar hukum yang berlaku surut adalah hak asasi manusia yang tidak dapat dikurangi dalam keadaan apapun.

Ketentuan ini mengakui adanya asas non retroaktif, dimana ditentukan bahwa hukum tidak berlaku surut. Kemudian UU No. 39 Tahun 1999 Pasal 4 merumuskan :

Hak untuk hidup, hak untuk tidak disiksa, hak kebebasan pribadi, pikiran dan hati nurani, hak beragama, hak untuk tidak diperbudak, hak untuk diakui sebagai pribadi dan persamaan dihadapan hukum, dan hak untuk tidak dituntut atas dasar hukum yang berlaku surut adalah hak asasi manusia yang tidak dapat dikurangi dalam keadaan apapun dan oleh siapapun.

Ketentuan ini juga mengakui asas nonretroakif, dimana orang tidak dapat dituntut berdasarkan hukum yang berlaku surut. Selanjutnya dalam UU No. 26 Tahun 2000 Pasal 43 ayat (1) dan (2) menentukan :

(1) Pelanggaran hak asasi manusia yang berat yang terjadi sebelum diundangkannya Undang undang ini, diperiksa dan diputus oleh Pengadilan HAM ad hoc"
(2) Pengadilan HAM ad hoc sebagaimana dimaksud dalam ayat (1) dibentuk atas usul Dewan Perwakilan Rakyat Republik Indonesia berdasarkan peristiwa tertentu dengan Keputusan Presiden

Dalam ketentuan ini dimungkinkan adanya pelanggaran HAM berat yang terjadi sebelum berlakunya undang undang tentang HAM yang diselesaikan melalui Pengadilan HAM ad hoc. Jika dilihat ketentuan hukum diatas terdapat kontradiksi di mana disatu sisi hukum melarang adanya asas retroaktif namun disisi lain membolehkan adanya asas retroaktif, tetapi harus melalui proses Dewan Perwakilan Rakyat.Ironisnya hasil dari sidang DPR diputus oleh presiden.

Merujuk latar belakang diatas maka dirumuskan permasalahan "Bagaimana kebijakan pemerintah dalam menyelesaikan pelanggaran HAM berat sebelum berlakunya UUNo. 39 Tahun 1999 dan UU No. 26 Tahun 2000 ditinjau dari aspek kemanusian dan hukum?

\section{METODE PENELITIAN}

Jenis Penelitian

Penelitianhukum (legal research) yaitu "penelitian untuk menemukan kebenaran koherensi, yaitu adakah aturan hukum yang sesuai dengan norma hukum dan norma perintah atau larangan sesuai dengan prinsip hukum serta apakah tindakan seseorang sesuai dengan norma hukum atau prinsip hukum".

Terkait dengan substansinya, penelitian ini merupakan penelitian hukum normatif. Pendekatan masalah yang dipergunakan dalam penelitian iniadalahpendekatan peraturan perundangundangan (statute approach), pendekatan konseptual (conceptual approach)dan pendekatan kasus (case approach)

\section{Sumber Bahan Hukum}

Bahan hukum yang digunakan adalah bahan hukum primer, yaitu bahan-bahan hukum yang mengikat. Bahan hukum primer yang digunakan diantaranya adalah 
Undang-Undang Dasar Negara Republik Indonesia Tahun 1945, Kitab UndangUndang Hukum Pidana, Undang-Undang Nomor 39 Tahun 1999 Tentang Hak Asasi Manusia, Undang-Undang Nomor 26 Tahun 2000 Tentang Pengadilan Hak Asasi Manusia. Bahan hukum sekunder terdiri dari kepustakaan yang membahas hukum yang menyangkut Hak asasi manusia, lembaga penegak hukum, DPR, jurnal dan surat kabar.

\section{Analisis Bahan Hukum}

Analisis bahan hukum dilakukan dengan terlebih dulu mengidentifikasi bahan hukum yang terkumpul, kemudian didiskripsikan, disistematisasikan dengan mendasarkan pada teori keilmuan hukum dan konsep-konsep ilmu hukum, prinsipprinsip atau asas-asas hukum. Selanjutnya, analisis bahan hukum yang dipergunakan adalah diskriptif analisis. Selanjutnya diambil kesimpulan dengan mengggunakan metode berpikir deduktif, yaitu menyimpulkan hasil penelitian dari hal yang sifatnya umum kepada hal yang sifatnya khusus. Penggunaan analisis bahan hukum yang demikian, diharapkan dapat menjelaskan permasalahan yang dirumuskan dalam penelitian ini secara memuaskan.

\section{PEMBAHASAN}

\section{Kebijakan HAM di Indonesia}

Perangkat hukum tentang HAM di Indonesia adanya setelah tuntutan reformasi berhasil menggulingkan rezim Orde Baru. Pemerintah Orde Baru yang berkuasa dengan politik demokrasi otoriternya, dengan berubahnya ke Pemerintahan Reformasi yang disemangati oleh demokrasi konstitusional, menuntut perubahan negara menjadi negara hukum yang menjujung Hak Asasi Manusia, bukan hanya sekedar slogan melainkan harus direalisasikan. Melalui semangat tersebut maka dikeluarkan Ketetapan
Ketetapan MPRRI No. XVII/MPR/1998 tentang HAM, selanjutnya ditindaklanjuti dengan mengeluarkan Undang -Undang Republik Indonesia Nomor 39 Tahun 1999 Tentang Hak Asasi Manusia (selanjutnya disingkat UURI No 39 Tahun 1999), kemudian pada tahun 2000 mengeluarkan Undang Undang Nomor 26 Tahun 2000 tentang Peradilan HAM (selanjutnya disingkat UURI No 26 Tahun 2000). Mendasarkan pada hukum HAM ini Pemerintah Reformasi ingin menyelesaikan masalah pelanggaran HAM berat di masa Pemerintah lama.

Kebijakan mengenai HAM yang mengakui adanya asas retroakktif menimbulkan isu yang menarik yang dikaji, sebab di satu sisi keinginan untuk memberikan jaminan terhadap setiap warga negara yang dijamin hak-hak konstitusional melalui Hak Asasi Manusia, namun di sisi lain mengancam pelaku pelanggaran hak asasi manusia yang terjadi di masa lalu, sehingga kebijakan yang diambil membuat kontrovesial, di mana letak jaminan kepastian hukumnya jika pengggaran terjadi sebelum undangundang terbentuk bisa diberlakukan pada untuk peristiwa yang lampau.

Kebijakan menurut Thomas $\mathrm{R}$ Dye merupakan pilihan apapun yang dilakukan oleh penguasa, baik dilaksanakan maupun tidak dilaksanakan, mendasarkan pada pendapat ini maka maka Hayat et.al berpendapat bahwa kebijakan publik bukan hanya dilakukan oleh pmerintah, tetapi juga apa saja yang tidak dilakukan oleh pemerintah ${ }^{3}$.

Pada tahun 2000 terjadi amandemen UUD 1945. Di dalam UUD 1945 amandemen yang diatur dalam Pasal 28 ayat (2) dirumuskan sebagai berikut :

"Setiap orang berhak bebas atas perlakuan yang bersifat diskriminatif atas dasar apa pun dan berhak mendapatkan perlindungan terhadap perlakuan yang bersifat diskriminatif itu".

${ }^{3}$ Hayat et.al, Reformasi Kebijakan Publik Perspektif Makro dan Mikro, I ed (Jakarta: Prenadamedia Group, 2018) 
Mendasarkan pada rumusan di atas dapat ditafsirkan, tidak mengakui adanya asas retroaktif, sebab bila asas retroaktif ini dijalankan maka yang terjadi adalah diskriminatif antara warga negara yang dulu berkuasa dengan warganegara yang sekarang berkuasa.

Mengenai HAM yang diatur dalam UUD 1945 sebelum amandemen, yang tertulis dalam Pasal 28, hanya ada satu ayat yaitu : "Kemerdekaan berserikat dan berkumpul, mengeluarkan pikiran dengan lisan dan tulisan dan sebagainya ditetapkan dengan undang-undang”. Jaminan HAM yang hanya satu ayat dalam Pasal 28 dianggap tidak cukup, karena itu untuk menjamin terhadap HAM perlu dilakukan perubahan Pasal 28 tersebut. Dalam perubahan UUD 1945 Pasal 28 tersebut pengaturan jaminan terhadap HAM Pasal 28 ditambah ayat mulai dari Pasal 28 huruf $\mathrm{a}$ - Pasal 28 huruf $\mathrm{j}$ sehingga menjadi 10 ayat. Jadi undang-undang tentang HAM yang mendasarkan pada TAP MPR No XVII/MPR/1998 tentang HAM seharusnya juga ditinjau ulang mengingat perubahan UUD RI 1945 dbuat setelah undangundang HAM terbentuk, dan tak bisa mempertahankan ketetapan MPR di atas, karena Ketetapan dalam struktur perundang-undangan berada di bawah UUD.

Melalui perubahan tersebut maka Warga Negara Indonesia secara yuridis telah dijamin Hak Asasinya, karena semua kebijakan tidak dibenarkan bertentangan dengan konstitusi. Jika terjadi kebijakan yang diatur dalam undang-undang bertentangan dengan UUD NRI Tahun 1945 maka bisa dilakukan hak uji materiil ke Mahkamah Konstitusi.

Dalam pandangan Laras Astuti di Indonesia pelanggaran merupakan tindakan pelanggaran kemanusiaan yang dilakukan baik oleh individu maupun oleh institusi negara atau institusi lainnya terhadap Hak Asasi Manusia ${ }^{4}$. Dalam

${ }^{4}$ Laras Astuti,Penegakan Hukum Pidana Indonesia Dalam Penyelesaian Pelanggaran Hak Asasi Manusia, Fakultas Hukum,Univrsitas undang-undang hak asasi ini, ternyata diberlakukan asas retroaktif, artinya bahwa peristiwa pelanggaran HAM berat yang terjadi sebelum diberlakukan UU No. 39 Tahun 1999 tersebut bisa dikenakan pada undang-undang yang baru. Kebijakan dalam undang-undang tersebut menjadi problematik sendiri sehingga timbul gugatan ke Mahkamah Konstitusi yang dilakukan oleh Abilio Jose Osorio Soares. Abilio Jose Osorio Soares tidak menerima dijadikan tersangka atas tindakan melanggar HAM di Timor Timur, sebab atas tuduhan pelanggaran HAM berat yang terjadi di Timor Timur tersebut sebelum berlakunya undang undang HAM, sehingga dia menolak atas berlakunya asas retroaktif tersebut yang dianggap melanggar hak konstitusional setiap warga negara sesuai yang diatur dalam Pasal $28 \mathrm{~J}$ UUD 1945.

\section{Negara Hukumdan HAM}

Kriteria suatu negara dikatakan sebagai negara hukum bilamana memenuhi persyaratan yang telah dirumuskan oleh bebarapa pakar. Pakar klasik seperti Emmatnuel Kant, Jullius Stahl dan A.V Dicey telah merumuskan kreteria negara hukum. Di negara eropa kontinental negara hukum disebut dengan Rechtsstaat yang dipeolopori oleh J. Stahl memberikan 4 kriteria negara hukum pertama adalah negara tersebut pengakuan terhadap hak asasi manusia; kedua adanya pemisahan kekuasaan; Pemerintah berdasarkan peraturan hukum yang berlaku (wetmatigheid van bestuur); keempat adanya peradilan tata usaha negara, sedangkan ajaran negara hukum dari Angelo Saxon yang dieplopri oleh A.V. Dicey yang dikenal dengan sebutan The Rule of Law memberikan tiga kreteria yaitu : pertama adanya equlaility before the law ; kedua supremacy of the law; Humans Rights. Selanjutnya dalam

Muhammadiyah Yogyakarta E-

mail:larasastuti@law.umy.ac.id, 2019 I476<http://doi:org/10.1017/CBO9781107415324.0 04>. 
pertemuan ahli hukum yang diselenggarakan di Bangkok pada tahun 1965 yang telah merumuskan kreteria negara hukum, dengan memberikan padangan yang lebih luas dengan memberikan konteks ; pertama adanya perlindungan kontitusional; kedua adanya kekuasaan kehakiman yang bebas dan tidak memihak, ketiga pemilihan umum yang bebas, ; keempat kebebasan untuk menyatakan pendapat; kebebasan utuk berserikat atau berorganisasi dan berekspresi; keenam pendidikan warga negara $^{5}$

Menurut Mukti Fajar dalam prateknya tidak ada negara yang melaksanakan konsep negara hukum ini secara berbeda-beda sebab setiap negara memiliki tujuan, sejarah dan politik yang tidak sama, tetapi secara konseptionalnya diadakan konsep negara hukum, tidak lain adalah bercita-cita untuk menjamin HAM untuk melindungi individu warga negara dari kesewenang-wenangan penguasa.

\section{AsasLegalitas}

Dalam negara hukum, Hak Asasi Manusia, tidak bisa dipisahkan sebab konsep dari negara hukum (rechtsstaat) unsur yang utama adalah hak asasi manusia, oleh sebab itu negara hukum memberikan jaminan hak asasi pada setiap warga negara. Selanjutnya dalam negara hukum ditentukan bahwa semua tindakan harus berdasarkan hukum yang berlaku, di mana hukum tersebut harus bersifat legitimate. Legitimate yaitu hukum tersebut harus dibentuk oleh lembaga yang memiliki kewenangan untuk membentuk hukum tersebut. Menurut Sirajudin dan Winardi yang mendasarkan pada pendapat Didi Nazmi menyatakan bahwa dalam negar hukum yang ditegakan adalah hukum yang bena benar baik dan berkeadilan serta tumbuh secara demokratis dan bersumber pada kedaulatan

${ }^{5}$ H.A. Mansyhur Effendi, Hak Asasi

Manusia Dalam Hukum Nasional dan

Internasional, I ed (Jakarta: Ghalia Indonesia, 1994) rakyat, yang berada dibawah pengawasan dengan prosedur yang konstitusinal ${ }^{6}$.

Legitimate dalam bahasa umum disebut dengan legitimasi. Dalam konteksi legitimasi ini E. Ferndando M Manullang menjelaskan dari berbagai pendapat pakar, dimulai dari Van Alpedorn yang memiliki gagasan bahwa legitime lahir dimulai dari ide J.J. Rousseua yang intinya undangundang merupakan pernyataan kehendak asli dari rakyat dan menjadi sumber satu satunya bagi pembentuk hukum, Hal ini berakibat kebiasaan ataupun prilaku yang timbul dari masyarakat tidak diakui oleh hukum, sebab kebiasaan tersebut bukan undang-undang, hal ini menjadikan negara sebagai wujud dari kedaulatan rakyat seperti yang digagas oleh J.J. Rousseau. Menurutnya J.M Van Bemmelen, legitimate selain J.J. Rousseau, yang lainnya adalah Montesqueieu yang juga menjelaskan mengenai asas legalitas bahwa legalitas berhubungan dengan konsep hak asasi manusia yang menyaakan asas ini tertulis dalam Dekclaration des drois de'homme et de citoyen (1789), kemudian juga tertulis dalam Bill of Rights yang menyatakan bahwa seseorang tidak dapat ditangkap atau ditutut tanpa kekuatan undang-undang. Cesare Beccaria yang juga ahli filsafat menyatakn bahwa hanya undang-undang yang boleh membuat hukum pidana bagi setiap tindak pidana karena adanya perjanjian dengan masyarakatyang, melalui perwakilannya kehendaknya seluruh kepentingan masyarakat yang berada dalam lembaga perwakilan, serta hakim tidak boleh menjatuhkan pidana kepada anggota masyarakat bilamana belum diatur dalam undang-undang ${ }^{7}$.

Berdasarkan penjelasan di atas bahwa legalitas itu berasal dari timbulnya ajaran J.J. Rousseua terhadap gagasannya

${ }^{6}$ Sirajuddin dan Winardi, Dasar Dasar Hukum Tata Negara Indonesia, (Malang Jatim: Setara Pers, 2015)

${ }^{7}$ E. Fenando M. Manullang, Legisme, legalitas dan Kepastian hukum, 2 ed. (Jakarta: KENCANA, 2017) 
mengeani kedaulatan rakyat, selain itu sesuai dengan pendapat dari J.M Van Bemmelen yang menyatakan bahwa legilitas berasal dari konsep hak asasi manusia sesui yang tertulis dalam dokumen dokumen hak asasi manusia, sedangkan menurut Beccaria legalitas merupakan ajaran dari kontrak sosial (perjanjian masyarakat) yang menjadi sumber dari hukum yang dibuat oleh lembaga perwakilan.

Asas legalitas sudah menjadi patokan di dalam rana hukum pidana selain itu juga menjadi prinsip pada semua negara yang menganut negara hukum. Walaupun asas legalitas ini sudah baku tetapi ada pula pendapat yang menyatakan bahwa asas legalitas yang melalui slogannya "nullum delictum, nulla poena sne praevia lege poenali" yang artinya tiada orang yang dapat dipidana tanpa adanya hukum pidana yang mengaturnya terlebih dahulu., hal ini yang dimaksud adalah tidak ada hukum yang berlaku surut (retroaktif) atau bisa dimaknai dengan slogan " lex temporis delicti" undang-undang berlaku terhadap delik yang terjadi pada saat itu ${ }^{8}$.

Berdasarkan hal di atas ini maka asas legalitas menjadi acuan bagi negara negara hukum namun konsep negara hukum ini berasal dari negara barat yang lebih mementingkan individu sebagai pihak yang mendapatkan perlindungan istimewa terhadap tindakan penguasa. Dalam hal memberikan jaminan terhadap indiidu ini maka asas legalitas dimasukan dalam Magna Charta 1215 dan Habeas Corpus Act 1679, kemudian masuk dalam Konstitusi Amerika Serikat Declaration of Independen (1783) dan diikuti Perancis dalam de Declaration dedroits de I'home et $d u$ citoyen 1789. Jadi dalam asas legalitas ini penganut utamanya adalah negara yang menganut negara hukum dan hak asasi manusia ${ }^{9}$. Sebaliknya pada negara negara berfaham sosialis seperti di Rusia pada tahun 1926 serta di German

\footnotetext{
${ }^{8}$ Bambang Poernomo, Asas Asas Huku

Pidana, 7 ed. (Jakarta: Ghalia Indonesia, 1994)

${ }^{9}$ Ibid
}

pada tahun 1935 tidak memberlakukan asas legalitas ini secara murni, negara negara yang berpaham sosialis umumnya menganut demokrasi otorian sehingga wajar jika hukum bisa diberlakukan surut, sebab faham mereka adalah bukan pada individu melainak melindungi kepentingan masyarakat banyak dan negara serta mengesam-pingkan kepentingan indvidu.

Di Indonesia sebelum terjadi reformasi juga tidak memegang prinsip murni asas legalitas walaupun dalam Pasal 1 KUHP jelas dicantumkan asas legalitas, hal ini disebabkan KUHP bukan merupakan konstitusi melainkan hanya sekedar undang-undang hukum kriminal serta mudah dirubah oeh lembaga perwakilan bersama pemerintah, yang membedakan dengan asas legalitas yang diatur dalam konstitusi, seperti di Amerika Serikat dan Perancis yang mencatumkan asas legalitas di dalam konstitusinya ${ }^{10}$. Jadi di Indonesia walaupun mengakui adanya prinsip negara hukum, hak asasi manusia dan asas legalitas, ternyata tidak sepenuhnya sebab mengakui adanya asas retroaktif yang sebenarnya sangat bertentangan dengan konsep negara hukum dan hak asasi manusia yang menjujung asas legalitas.

\section{Kendala/KesulitandalamPenyelesaianPe rkara HAM Berat}

Bilamana konsep negara hukum hanya untuk menghiasi saja konstitusi demikian pula asas legalitas yang diakui hanya separuh saja, sehingga hukum melegalkan retroaktif, berarti negara ini tidak memiliki jaminan kepastian hukum serta perlindungan HAM, Prinsip HAM adalah melindungi bagi orang orang yang lemah. Orang-orang yang lemah di negara negara otoriter memang tidak mendapatkan perlindungan. Indonesia semenjak tahun 1959 sampai 1998 menganut demokrasi otoriter. Semua tindakkan pemerintahan waktu itu, tidak ada yang berani menentang, bahkan

${ }^{10}$ H.A. Mansyhur Effendi, Loc. Cit 
mengikutinya, setelah reformasi keadaan menjadi sebaliknya, dimana penguasa baru berkeinginan menyelesaiakan permasalahan HAM berat yang terjadi pada waktu demokrasi otoriter, kemudian membuat hukum baru yang demokratis, melalui pembentukan undang-undang HAM serta merubah konstitusi dengan mengakui semua konsep konsep negara hukum dan asas legalitas untuk memberikan jaminan terhadap kemanusiaan. Permasalahannya apakah hukum yang baru tersebut bisa diberlakukan untuk kejahatan pada waktu yang lampau dengan kondisi telah terjadi perubahan hukum besar-besaran dari demokrasi otoriter ke demokrasi konsitusional yang dilakukan dengan cara evolusi, bukan revolusi.

Mahkamah Konsitusi (MK) pada Perkara No. 065 /PUU-II/2004 masalah retroaktif memberikan pertimbangan sebagai berikuti :

Menimbang bahwa berdasarkan uraian di atas, sebagian dari dalil Pemohon yang dijadikan dasar penolakan terhadap pengesampingan asas non-retroaktif adalah dapat dibenarkan sepanjang menyangkut kejahatan-kejahatan biasa (ordinary crimes) ataupun kejahatan luar biasa (extraordinary crimes) yang cukup diadili melalui forum pengadilan biasa dan tanpa harus mengesampingkan asas nonretroaktif. Namun, dalil-dalil tersebut tidak dapat digunakan untuk membangun konstruksi pemikiran hukum (legal construction) yang bersifat aksiomatik sehingga melahirkan kesimpulan bahwa hak untuk tidak dituntut berdasarkan hukum yang berlaku surut adalah hak asasi manusia yang bersifat mutlak. Sebab, jika konstruksi pemikiran demikian digunakan maka terhadap perbuatan-perbuatan yang tergolong ke dalam kejahatan-kejahatan luar biasa (extraordinary crimes) yang secara universal telah dianggap sebagai kejahatan serius terhadap masyarakat internasional secara keseluruhan (the most serious crimes of concern to the international community as a whole), yang di dalamnya termasuk kejahatankejahatan sebagaimana diatur dalam undang a quo, sangat mungkin lolos dari tuntutan hukum tatkala hukum atau undang-undang tidak secara tegas mengatur perbuatan-perbuatan demikian sebagai kejahatan. Apabila itu terjadi, maka telah terjadi pelanggaran terhadap suatu prinsip fundamental yang telah diterima secara universal sebagai asas hukum yaitu "tidak boleh ada kejahatan yang dibiarkan berlalu tanpa hukuman" (aut punere aut de dere). Konstruksi pemikiran hukum aksiomatik yang mengabsolutkan asas non-retroaktif, secara rasional, berarti juga harus diartikan sebagai penolakan terhadap mekanisme keadilan transisional (transitional justice) yang merupakan mekanisme penyelesaian pelanggaran-pelanggaran hukum yang terjadi di masa lalu, terutama pelanggaran berat terhadap hak-hak asasi manusia. Sebab, mekanisme keadilan transisional (transitional justice), terlepas dari sedikit banyaknya, pasti mengandung elemen pengesampingan asas nonretroaktif;

Menimbang bahwa dari seluruh uraian di atas jelas Pasal 43 ayat (1) dan ayat (2) Undang-undang Negara Republik Indonesia Nomor 26 Tahun 2000 tentang Pengadilan Hak Asasi Manusia (Lembaran Negara Republik Indonesia Tahun 2000 Nomor 208, Tambahan Lembaran Negara Republik Indonesia Nomor 4026) sebagaimana dimohonkan oleh Pemohon, tidak terbukti bertentangan dengan Undang-Undang Dasar Negara Republik Indonesia Tahun 1945, dan oleh karenanya permohonan Pemohon harus dinyatakan ditolak; 
Dalam Perkara Gugatan di MK diputuskan Pemohon Hak Uji Materiil terhadap Undang-Undang Nomor 39 Tahun 1999 ditolak oleh Majelis Hakim Mahkamah Konstitusi, dalam Putusan tersebut sebenarnya tejadi dissenting opinion, yaitu Ada tiga hakim yang berbeda pendapat (dissenting opinion). Hakim yang menolak yakni:

H. Achmad Roestandi, S.H. menyatakan bahwa

"Penerapan asas retroaktif bertentangan dengan asas hukum yang dianut oleh hampir seluruh sistem hukum pidana di dunia. Asas retroaktif, memang pernah diterapkan di dalam pengadilan, tetapi pengadilan yang melakukannya adalah pengadilan internasional seperti dalam pengadilan di Nuremberg, Tokyo, Rwanda, dan Yugoslavia. Walaupun di dalam hukum internasional, dalam keadaan tertentu dan darurat, pernah diterapkan asas retroaktif, tetapi pada akhirnya selalu kembali kepada sikap untuk tidak menerapkan asas tersebut. Dalam lingkup nasional, bahkan negara paling maju dan "beradab", seperti Amerika Serikat, tetap mempertahankan asas non-retroaktif sebagaimana tercantum dalam Article I Section 9 Konstitusinya yang berbunyi: "No bill of attainder or ex post facto law shall be passed";

Kemudian Hakim Prof. Dr. H.M. Laica Marzuki, SH berpendapat

"bahwa asas non-retroactive dilarang konstitusi. Pasal 28I ayat (1) UUD NRI Tahun 1945 menentukan bahwasanya “....hak untuk tidak dituntut atas dasar hukum yang berlaku surut adalah hak asasi manusia yang tidak dapat dikurangi dalam keadaan apapun". Asas non-retroactive adalah amanah dan perintah konstitusi, tidak dapat disimpangi, apalagi dinegasi oleh peraturan perundang-undangan lainnya.
Constitutie is de hoogste wet! ---Larangan penerapan asas retroaktif tidak lagi sekadar diatur pada Pasal 1 ayat (1) KUH Pidana yang memuat asas 'nullum delictum, nulla poena sine preavia lege poenali', walau pun prinsip Nullum Delictum dimaksud memang pernah - secara buiten werking gesteld - dikesampingkan oleh pemerintah pendudukan NICA di tahun 1945, berdasarkan stbl 1945 nr 135, lebih dikenal dengan nama Brisbane Ordonnantie, tetapi asas nonretroaktif sudah tidak dapat disimpangi, apalagi dilanggar, dengan telah dicantumkannya prinsip tersebut pada Pasal 28I UUD NRI Tahun 1945. Juga Pasal 28I UUD NRI Tahun 1945 tidak dapat di-negasi oleh Pasal 28J UUD NRI Tahun 1945 yang hanya menetapkan pembatasan penggunaan hak dan kebebasan setiap orang atas dasar undangundang dalam makna wet, Gesetz, tetapi sama sekali bukan dalam makna pembatasan atas dasar Grundgesetz (undang-undang dasar)"

selanjutnya Prof. H. Abdul Mukthie Fadjar, SH, M.S. sebagai hakim dalam perkara ini yang berpendapat dengan menyitir Firman Tuhan :

"Dalam perspektif teologis, nukilan firman Tuhan dari penggalan ayat Al Quran tersebut di atas, menunjukkan bahwa betapa Tuhan sendiri sebagai Sang Maha Pencipta tidak menerapkan asas retroaktif bagi risalah agama, termasuk hukum-hukumnya, sebelum ada hukum yang termuat dalam risalah agama yang dibawa oleh para rasul diberlakukan buat suatu ummat"

Ketiga pendapat hakim di atas ini memang tepat sebab jika asas retroactif ini dipaksakan berlaku maka akan berakibat 
kasus kasus lama pun bisa diberlakukan hukum yang baru, dan tak menutup kemungkinan Penjajah Belanda, Jepang yang pernah menjaja Indonesia seharusnya dikenakan juga, demikian semua penguasa lama masa demokrasi otoriter idealnya juga bisa dikenakan undang-undang tentang HAM ini.

Menurut Jonathan Aprilino

Soegijanto pada masa pemerintah Orde Baru belum memahami HAM dengan baik, karena tidak ada kebebasan untuk berpendapat, atau pun kebabasan pers, berserikat dan sebagainya, setelah jatuhnya rezim Orde baru, barulah masyarakat sadar akan pentingnya HAM dan muncul isu isu untuk menuntut pelanggaran HAM pada masa itu, dalam menggatasi itu maka pemerintah reformasi mengeluarkan Ketetapan MPR Nomor XVII/MPR/ 1998 yang kmudian ditindaklanjuti dengan dikeluarkan Undang-Undang Nomor 39 Tahun 1999 mengutip dari pendapat Bagir Manan terhadap hukum HAM yang belaku di Indonesia yakni "Pertama, terdapat ketentuan yang tidak memuat norma atau kaidah, dan hal ini ditunjukkan dengan adanya bab mengenai asas-asas Dasar. Asas-asas dasar pada prinsipnya bukan merupakan kaidah atau norma hukum. Jadi, asas tidak perlu secara eksplisit dimuat dalam UU melainkan akan menjiwai pasal-pasal yang ada dalam UU bersangkutan. Kedua, penyimpangan terhadap asas bahwa hukum tidak berlaku surut seharusnya tidak diletakkan pada Bagian Penjelasan, melainkan pada Bagian Batang Tubuh UU. Hal ini disebabkan Penjelasan tidak memuat norma atau kaidah, Atau dengan kata lain penjelasan tidak berfungsi untuk menciptakan kaidah hukum"11.

Perkara HAM di Indonesia, pelanggarn HAM bisa diadili di Pengadilan HAM Ad Hok tetapi untuk membawa perkara HAM tersebut, harus

\footnotetext{
${ }^{11}$ Jonathan Aprilino Soegijanto, "Asas Retroaktif yang Berlaku dalam Undang-Undang Peradilan HAM, LEGAL STANDING, 2. Tentang HAM (2018), 26
}

melalui DPR dan Pemerintah terlebih dahulu untuk menentukan apakah perkara tersebut tergolong pelanggaran HAM berat atau bukan, artinya tidak bisa langsung, sehingga suatu kasus tersebut tergolong HAM atau bukan tergantung dari DPR dan Pemerintah.

Proses ini bukan merupakan kaidah hukum melainkan kaidah politik. Jadi aturan perundangan tentang hak asasi manusia kelemahannya tidak diselesaikan melalui hukum terlebih dahulu tetapi melalui proses politik. MK sebagai Mahkamah Penjaga hukum justru memperkuat kelemahan tersebut terbukti dengan menolak gugatan pemohon.

Dalam UUD 1945 sudah dirumuskan bahwa Indonesia adalah negara hukum bukan negara politik, oleh karena jika kasus HAM di Indonesia diserahkan pada DPR maka akan diproses melalui jalur politik. Selain itu, jika asas retroaktif ini diberlakukan maka akan terkesan, pelanggaran HAM akan diselesaikan dengan melanggar HAM pula karena tidak sesuai dengan asas legalitas dan konsep Negara Hukum yang menjujung tinggi HAM.

Pendapat dari Prof. DR. Soedjono Dirdjosisworo, dalam bukunya, "Pengadilan Hak Asasi Manusia Indonesia", 2002, halaman 18, yang dijadikan salah satu dalil dari Pemerintah dalam perkara tersebut menyatakan pada pokoknya "bahwa pemberlakuan asas retroaktif dapat dilakukan dengan menggunakan Pasal 28J Undang-Undang Dasar Negara Republik Indonesia Tahun 1945 atau dengan kata lain untuk melindungi hak asasi manusia asas retroaktif dapat digunakan"

Jadi mendasarkan salah satu pendapat di atas Majelis Hakim MK menerima asas retroaktif bisa dilakukan dengan mendasarkan pada penafsiran dari pasal 28 J dan 28 I UUD 1945. Menurut Agus Raharjo dengan mengutip pendapat H.A. Mansyhur Effendi bahwa asas retroaktif ini bisa saja diberlakukan tetapi dengan beberapa perkecualian, dengan 
memberikan contoh dalam di Mahkamah pidana internasional Nuremberg 1946 dan Tokyo 1948 yang mengadili penjahat perang pada Perang Dunia International Criminal Tribunal for the Former Yugoslavia (ICTY)17 dan International Criminal Tribunal for Rwanda (ICTR)18 merupakan contoh penerapan asas retroaktif $^{12}$.

Mendasarkan pada adanya perkecualian memberlakukan asas retroaktif dengan kondisi dalam kedaan perang. Dalam Perang akan terjadi siapa yang menang dan kalah. Bagi pihak pemenang selalu memiliki gigi untuk menutut terhadap yang kalah, hal ini logis. jika menggunakan dalil tersebut dikatikan dengan Indonesia Pertanyaannya adalah apakah Indonesia saat Soeharto mundur sebagai Presiden dapat dinyatakan sebagai kalah perang?

Mundurnya Soeharto tidak dalam keadaan Perang, Soeharto mundur dilakukan secara konstitusional, dimana kemudian diganti oleh Wakilnya yaitu B.J. Habibie dan rezimnya tetap memegang kekuasaan, karena itu tidak bisa dinyatakan kalah perang, dengan kata lain Indonesia bukan dalam keadaan kalah perang, walaupun mundurnya Soeharto atas desakan Mahasiswa tetapi tidak bisa dinyatakan kalah perang.

Jadi karena berubahnya kondisi politik dari demokrasi otoriter ke demokrakrasi konstsitusional, bukan dalam keadaan perang, Oleh sebab itu, memberlakukan dengan pengecualian tidak bisa diberlakukan di Indonesia. Hak retroaktif tidak diberlakukan pada negara negara yang mendasarkan pada hukum serta menjamin hak asasi masnusia Jaminan HAM dan kepastian hukum diberikan pada setiap individu, tapi bukan dengan cara tebang pilih.

\section{PerkaraTanjungPriok Dan Pelanggaran HAM di Papua}

Dalam penegakan HAM berdasarkan UU RI No. 39 Tahun 1999 utamanya sebelum ditingkat penegak hukum ditangani oleh Komisi Nasional Hak Asasi Manusia (Komnas HAM). Terlebih dahulu untuk menentukan apakah tindakan kekerasan tersebut tergolong pelanggaran HAM berat, jika bukan pelanggaran HAM berat maka diselesaikan melalui kepolisian sebagai delik umum, sebaliknya jika oleh Komnas HAM tindakan tersebut dinyatakan pelanggaran HAM berat maka diselesaikan melalui proses hukum ke pengadilan HAM.

Sebagaiman diketahui bahwa Komnas HAM dibentuk pada tahun 1993 berdasarkan Keputusan Presiden Nomor 50 Tahun 1993 tentang Komisi Nasional Hak Asasi Manusia (selanjutnya disingkat Keppres No. 30 Tahun 1993). Pembentukan Komnas HAM ini adalah sesuai dengan Pasal 4 Keppres No. 30 Tahun 1993 bertujuan :

a. membantu pengembangan kondisi yang kondusif bagi pelaksanaan hak asasi manusia sesuai dengan Pancasila, Undang-Undang Dasar 1945, dan Piagam Perserikatan Bangsa-Bangsa serta Deklarasi Universal Hak Asasi Manusia;

b. meningkatkan perlindungan hak asasi manusia guna mendukung terwujudnya tujuan pembangunan nasional yaitu pembangunan Manusia Indonesia seutuhnya dan pembangunan masyarakat Indonesia seluruhnya.

Sedangkan kegiatannya sesuai dengan Pasal 5 Keppres No. 50 Tahun 1993 tersebut yaitu untuk mewujudkan tujuan sebagaimana dimaksud dalam Pasal 4, Komisi Nasional melakukan kegiatan sebagai berikut :

a. menyebarluaskan wawasan nasional dan internasional mengenai asasi manusia baik kepada masyarakat Indonesia 
maupun kepada masyarakat Internasional;

b. mengkaji berbagai instrumen Perserikatan Bangsa-Bangsa tentang hak asasi manusia dengan tujuan memberikan saran-saran mengenai kemungkinan aksesi dan/atau ratifikasinya;

Mendasarkan pada dasar di atas tugas dan tujuan dari Komnas HAM hanya sebagai komisi yang mengembangkan, mewujudkan, menyebarluaskan wawasan tentang hak asasi manusia dan sama sekali tidak ada kaitannya dengan penegakan hukum HAM. Status Komnas HAM ini menjadi lebih legitime dengan dikeluarkannya UU RI No. 39 Tahun 1999, dimana dalam Pasal 75 UU RI No. 39 Tahun 1999 dirumuskan bahwa Komnas HAM bertujuan :

(1) mengembangkan kondisi yang konduksif bagi pelaksanaan hak asasi manusia sesuai dengan Pancasila, Undang-Undang Dasar 1945, dan Piagam Perserikatan Bangsa-Bangsa, serta Deklarasi Universal Hak Asasi Manusia; dan

(2) meningkatkan perlindungan dan penegakan hak asasi manusia guna berkembangnya pribadi manusia Indonesia seutuhnya dan kemampuannya berpartisipasi dalam berbagai bidang kehidupan" Dalan Pasal 76 ayat (1) UU RI No. 39 Tahun 1999 tersebut dirumuskan "Untuk mencapai tujuannya, Komnas HAM melaksanakan fungsi pengkajian, penelitian penyuluhan, pemantauan, dan mediasi tentang hak asasi manusia."

Melihat kedua pasal di atas menunjukkan bahwa tugas dan tujuan dibentuknya Komnas HAM hampir sama dengan yang diatur dalam Keppres No. 50 Tahun 1993 yaitu bersifat hanya memberikan mediasi, penyuluhan , pengkajian mengembangkan dan sebagainya tentang HAM dan yang sama sekali tidak bersangkut paut dengan penegakan hukum. Penegak hukum masih berada pada kepolisian dan kejaksaan tentang pelaku tergolong tindak pidana pelanggaran HAM berat, ringan untuk diteruskan tetap berada di kedua lembaga tersebut.

Kebijakan pemerintah dalam menyelesaikan kejahatan HAM berat yang terjadi di masa demokrasi otoriter tersebut akan diselesaikan berdasarkan UndangUndang Republik Indonesia Nomor 39 Tahun 1999 Tentang Hak Asasi Manusia dan Undang-Undang Republik Indonesia Nomor 26 Tahun 2000 tentang Peradilan Hak Asasi Manusia. Hal ini berarti kedua undang-ndang tersebut dapat berlaku surut, artinya kedua undang-undang HAM menganut asas retroaktif. Mulai tahun 2000 sampai tahun 2004 telah terjadi empat kali perubahan Undang-Undang Dasar 1945. Dalam UUD 1945 perubahan sesuai dengan Pasal 28I menganut asas retroaktif, artinya konstitusi ini melarang hukum berlaku surut.

Berdasarkan Pasal (4) dan (5) Undang-Undang Nomor 26 Tahun 2000, Pengadilan HAM bertugas dan berwenang untuk memeriksa dan memutus perkara pelanggaran HAM yang berat dan berwenang pula memeriksa dan memutus perkara pelanggaran HAM berat yang diluar batas teritorial wilayah negara Republik Indonesia oleh warga negara Indonesia. Pelanggaran HAM yang berat yang terjadi sebelum diundangkannya Undang-Undang ini Nomor 26 Tahun 2000, diperiksa dan diputus oleh Pengadilan HAM Ad Hoc yang berada dalam lingkungan Peradilan Umum yang pembentukannya atas usul Dewan Perwakilan Rakyat Republik Indonesia berdasarkan peristiwa tertentu dengan Keputusan Presiden. Dalam hal Dewan Perwakilan Rakyat Republik Indonesia mengusulkan dibentuknya Pengadilan HAM Ad Hoc, Dewan Perwakilan Rakyat Indonesia mendasarkan pada dugaan telah terjadinya pelanggaran Hak Asasi Manusia yang berat yang dibatasi pada locus dan tempus delicti tertentu yang terjadi 
sebelum diundangkannya Undang-Undang Nomor 26 Tahun 2000 tentang Pengadilan Hak Asasi Manusia. (Pasal 43).

Menurut ketentuan pasal 43 ayat $1 \mathrm{UU}$ No. 26 Tahun 2000 tentang Pengadilan Hak Asasi Manusia, pelanggaran HAM berat yang terjadi sebelum berlakunya UU tersebut dapat diselesaikan melalui Pengadilan HAM Ad hoc yang dibentuk dengan Keputusan Presiden atas usul DPR. Berkenaan dengan penyelesaian pelanggaran HAM masa lalu, Jose Zalaquett berpendapat, bahwa negara pada dasarnya mempunyai diskresi untuk menetapkan substansi kebijakan untuk menangani pelanggaran HAM masa lalu. Namun di dalam semua kasus substansi kebijakan itu harus memenuhi syaratsyarat legitimasi tertentu sebagai berikut:

1. Kebenaran harus diketahui atau diungkapkan secara lengkap, dan diekspos serta diumumkan kepada publik;

2. Kebijakan HAM tersebut harus mewakili kehendak rakyat, misalnya kebijakan nasional itu harus memperoleh persetujuan rakyat melalui referendum;

3. Kebijakan HAM tersebut tidak melanggar hukum HAM internasional. Yang berarti pada satu sisi menjadi kewajiban setiap negara untuk bertindak sesuai dengan hukum internasional. Bila negara mengambil langkah untuk memberikan pengampunan bagi pelanggar HAM, kebijakan tersebut harus tunduk pada batas-batas yang diatur oleh hukum internasional. Pada sisi yang lain, jika kebijakan HAM itu mengarah pada penghukuman, standar-standar internasional yang berkenaan dengan penyelenggaraan pengadilan yang adil, perlakuan terhadap para tersangka dan penghukuman wajib dihormati;

4. Kebijakan HAM tersebut mengandung tujuan-tujuan untuk mereparasi kerugian yang diderita korban dan pencegahan berulangnya pelanggaran HAM di kemudian hari. ${ }^{13}$

Perkara Tanjung Priok yang terjadi tahun 1978 diadili pada tahun 2003-2004, kasus tersebut sudah berjalan 25 tahun baru diperkarakan di Pengadilan. Melihat perkara tersebut terlambat diajukan ke pengadilan, bukan karena kelemahan dari penegakkah hukum melainkan kondisi demokrasi yang berjalan saat itu adalah demokrasi otoriter sehingga hukum yang berlaku juga kolot, selain itu tidak ada undang-undang tentang HAM saat itu sehingga penegak hukum tak mungkin melaksanakan tugasnya.

Perkara Tanjung Priok yang sudah lama itu, dipaksakan untuk diajukan di Pengadilan oleh kejaksaan, sehingga tidak heran jika banyak kelemahan dan keunikan yang terjadi dalam persidangan tersebut. Menurut Elsam (Ormas Pengamat HAM), melihat permasalahan dalam kasus Tanjung Priok yang tanggal 12 September 1978, yang melibatkan dan menahan Pengurus Mesjid di Tanjung Priok oleh Pemerintah, yang pada akhirnya terjadi bentrok antara aparat dengan pengikut Amir Biki. Dalam bentrokan tersebut terjadi penembakan oleh Aparat terhadp para demontran yang menimbulkan korban. Peristiwa tersebut yang terjadi tahun 1978 dan baru disidangkan sekitar tahun 2003 -2004 dengan mendasarkan pada UU No. 39 Tahun 1999.

Acara persidangan dalam pandangan ELSAM, sangat kontroversial, sebab "bagaimana mungkin terhadap satu peristiwa yang sama, fakta yang sama, saksi-saksi yang sama dan proses persidangan yang sama, dapat menghasilkan putusan yang berbeda?".

13 Abdul Hakim G Nusantara. "Pelanggaran HAM Berat dan Kebijakan Nasional Untuk Penanganan dan Penyelesaiannya". Http://www.komnasham.go.id/portal/files/AHGNPelanggaran Berat_HAM dan Kebijkan_Nasional. Diakses tanggal 24 Februari 2010 
Dalam kasus tersebut terdapat dua terdakwa yaitu Sutrisno Mascung dan anak buahnya. Masing dihukum 3 tahun untuk Sutrisno, sedangkan anak buahnya dihukum 2 tahun. Hukuman ini yang dianggap kontroversial oleh Elsam, sedangkan untuk Komandan Kodim 0502 Jakarta, dijatuhi hukuman 10 tahun.

Pengadilan HAM Jakarta Pusat juga telah "membebaskan" dua orang terdakwa lainnya, yaitu Pranowo pada 10 Agustus 2004 dan Sriyanto 12 Agustus 2004. Dalam putusannya, Majelis Hakim menyatakan bahwa (kedua) terdakwa tidak terbukti secara sah dan menyakinkan bersalah melakukan kejahatan terhadap kemanusiaan sebagaimana didakwakan Jaksa. Dan oleh karenanya, (kedua) terdakwa harus dibebaskan dari segala dakwaan.

Jadi dalam Perkara HAM yang diselesaikan oleh Pengadilan HAM, ada beberapa terdakwa, dimana dalam proses penyelesaian perkara tersebut, ada terdakwa yang dihukum dan ada pula yang dibebaskan. Hal inilah yang menjadi sorotan bagi ELSAM. Mereka melihat banyak kejanggalan dalam persidangan tersebut, seperti para saksi tidak memberikan keterangan yang meyakinkan bahkan tak jarang yang justru memberikan keterangan yang meringankan, serta para komandan pemegang komando, seperti :

1. Jend. TNI Benny Moerdani, Panglima TNI-Pangkopkamtib;

2. Mayjend. TNI Tri Sutrisno, Pangdam V Jaya;

3. Brigjend. TNI Dr. Soemardi, Kepala RSPAD Gatot Subroto;

4. Mayor TNI Darminto, Bagpam RSPAD Gatot Soebroto;

5. Kapten Auha Kusin, BA, Rohisdam V Jaya; dan

6. Kapten Mattaoni, BA, Rohisdam V Jaya

Para komandan ini tidak diajukan saksi sama sekali sehingga menurut ELSAM sidang di Pengadilan HAM kurang meyakinkan. Mengenai dasar tuntutan Jaksa menggunakan pasal-pasal KUHP.
Pasal-pasal yang digunakan adalah pasalpasal yang terdapat dalam Ketentuan Umum (Buku I). Dalam surat dakwaan terhadap terdakwa Sutrisno Mascung, dkk, pasal KUHP yang digunakan dalam dakwaan kesatu dan kedua adalah Pasal 55 ayat (1) ke-1 KUHP. Dalam surat dakwaan terhadap Sriyanto, pasal-pasal KUHP yang digunakan adalah Pasal 55 ayat (1) ke-1 KUHP dan Pasal 53 ayat (1) KUHP. Sedangkan, dalam surat dakwaan terhadap Pranowo dalam dakwaan pertama menggunakan Pasal 55 ayat (1) ke-1 dan Pasal 64 KUHP, dakwaan kedua menggunakan Pasal 64 KUHP.

Melihat dasar tuntutan jaksa di atas menunjukan bahwa bukan pasal-pasal dalam Undang-Undang No. 26 Tahun 2000 sehingga perkara tersebut bukan merupakan pelanggaran HAM berat melainkan perkara kejahatan biasa (ordenary crime). Jadi dalam Putusan MK tetap mempertahuan Undang-Undang No. 26 Tahun 2000 dan Undang-Undang No. 39 Tahun 1999 bisa dijadikan dasar dalam perkara HAM berat yang terjadi sebelum UU No. 39 Tahun 1999 dan UndangUndang No. 26 Tahun 2000 berlaku, namun dalam praktek Pengadilan HAM, undang-undang tersebut tidak diberlakukan, melainkan tetap memberlakukan KUHP sebagai dasar tuntutan dan Putusan Pengadilan HAM ad hoc.

Peristiwa Penganiayaan yang terjadi di Papua Barat, dimana puluhan penduduk sipil ditahan di Markas Brimob Papua, mereka ditendang, disiksa, serta dianiaya sehingga menimbulkan satu orang korban meninggal, akibat dari peristiwa tersebut maka Komandan Brimob bernama Kombes.Pol. Drs. Daud Sihombing, SH, diajukan ke Pengadilan HAM atas tuduhan melakukan pelanggaran HAM berat, tanggal 7 sampai dengan tanggal 15 Desember 2000 atau setidak-tidaknya dalam tahun 2000, bertempat di Markas Kepolisian Resort Jayapura atau setidaktidaknya pada tempat-tempat lain yang masih termasuk dalam daerah hukum 
Pengadilan Hak Asasi Manusia ( HAM ) pada Pengadilan Negeri Makassar, tidak melakukan pengendalian secara patut dan benar terhadap bawahannya yang berada di bawah kekuasaan dan pengendaliannya yang efektif, dimana terdakwa mengetahui atau secara sadar mengabaikan informasi yang secara jelas menunjukkan bahwa bawahannya sedang melakukan atau baru saja melakukan pelanggaran Hak Asasi Manusia (HAM) yang berat. yakni berupa pembunuhan, dengan tuntutan Pasal 42 ayat (1) huruf a dan b, Pasal 9 huruf h, Pasal 37 dan pasal 40 Undang-undang No. 26 tahun 2000, pasal-pasal dari UndangUndang No. 8 tahun 1981, UndangUndang No.39 Tahun 1999 dan Undangundang No. 5 Tahun 2004 yang bersangkutan. Perkara ini pantas diajukan ke Pengadilan HAM di Makasar sebab peristiwa terjadi setelah Undang-Undang HAM terbentuk sehingga layak jika Peradilan mendasarkan pada hukum HAM. Namun dalam perkara No. 02 K/PID.HAM AD HOC/2006, Terdakwa dinyatakan tidak terbukti melakukan pembunuhan serta tidak melakukan tindakan pelanggaran HAM berat.

Melihat penyelessaian dua kasus perkara HAM berat di Indonesia, dapat diamati tidak dapat memuaskan semua pihak, sebab banyak kendala yang dihadapi, diantaranya, jika kita melihat kasus HAM yang terjadi di Masa Orde Baru, dimana dalam masa tersebut belum ada undang-undang HAM sehingga jika dipaksakan undang-undang HAM yang diaplikasikan maka sama saja penyelesaian HAM dilaksanakan dengan melanggar HAM pula, walaupun MK dalam putusannya menerima asas retroaktif tetapi di pengadilan HAM ad hod di Jakarta Pusat tetap tidak mendasarkan putusannya pada undang-undang HAM melainkan mendasarkan pada KUHP sehingga kasus pelanggaran HAM tersebut, bukan merupakan pelanggaran HAM.

Masalah lainnya kendala terhadap peristiwa pelanggaran HAM sebelum terbentuknya undang-undang HAM, dari aspek hukum, para hakim tentu memiliki penafsiran yang berbeda-beda tentang berlakunya hak retroaktif tersebut, bahkan di MK sendiri juga terjadi dissenting, apalagi di hakim hakim di luar MK, bisa saja mereka memiliki penafsiran yang berbeda terhadp hak retroaktif tersebut, dalam undang-undang HAM sendiri, masalah pelanggaran HAM berat tidak serta merta bisa diajukan ke pengadilan HAM, melainkan harus melalui proses sidang DPR dan Pemerintah,.

Dalam aspek politis, lebih banyak kendala lagi, diantaranya masih banyak penguasa penguasa lama memiliki pengaruh besar terhadap penguasa baru sehingga tidak mudah membawa perkara pelanggaran HAM berat kedalam proses hukum, bisa dilihat dari pemeriksaan perkara Tanjung Priok di atas, dimana Jaksa tidak mengajukan sama sekali para komandan yang memegang komando, jaksa hanya membawa saksi-saksi yang kurang memadai sehingga justru meringankan para terdakwa.

Proses persidangan di Pengadilan HAM Makasar melaksanakan pemeriksaan dengan mendasarkan pada undang-undang HAM . karena peristiwa di Papua terjadi saat undang-undang HAM sudah ada, tetapi oleh Majelis Hakim memutuskan membebaskan terdakwa dari segala tuntutan dengan pertimbangan bahwa tidak ada kaitan antara matinya korban dengan tindakan terdakwa.

Dalam masalah penyelesaian pelanggaran HAM berat di Indonesia di masa lalu tidak bisa diharapkan diselesaikan dengan baik, bilamana kondisi masih seperti sekarang, sebab di llihat dari aspek politik, masih banyak penguasa lama sampai sekarang masih berpengaruh. selain itu terbentuknya undang undang hak asasi manusia menjelang abad ke-21, padahal banyak kasus pelangaran HAM berat terjadi dimasa lampau terutama di masa demokrasi otoriter.

Dalam pandangan Bambang Heri Supriyanto mengenai penyelesaian kasus 
pelanggaran HAM berat di Indonesia tidak bisa diselesaikan sepanjang pemikirannya hanya bersandar pada nilai nilai standart dalam satu negara, sebab nilai nilai setiap negara tidak seragam banyak dipengaruhi oleh kultur, religius, lingkungan dan sebagainya, jika berkeinginan menyelesaikan kasus pelanggaran HAM harus sesuai dengan kaidah dan nilai nilai yang ada pada Bangsa Indonesia, jika tidak maka persepsi terhadap HAM hanya terbatas pada platform saja ${ }^{14}$.

\section{KESIMPULAN}

Penyelesaian perkara HAM di masa lalu, diselesaikan dengan membentuk Pengadilan HAM ad hoc di Jakarta, berdasarkan Instruksi Presiden tetapi hakimdalam persidangan menggunakan hukum pidana biasa, yaitu KUHP tidak mendasarkan pada UU No.26 Tahun 2000 walaupun Pemerintah dan MK melegalkan asas retroaktif. Pelanggaran HAM yang terjadi setelah disahkan UU No. 39 Tahun 1999 dan UU No. 26 Tahun 2000 adalah pelanggaran HAM yang diselesaikan melalui Pengadilan HAM di Makasar, mendasarkan pada UU No. 26 Tahun 2000 dan UU No. 39 Tahun 1999 tetapi oleh Majelis Hakim di PN Makasar, para terdakwa dibebaskan dari segala tuntutan dengan dalih kematian korban tidak ada kaitannya dengan tindakan terdakwa.

\section{REKOMENDASI}

Karena negara Indonesia adalah negara hukum maka pemerintah seharusnya tidak memberlakukan asas retroaktif, karena konsep negara hukum adalah adanya asas Legalitas. Tetapi jika akan memberikan rasa keadilan bagi

\footnotetext{
${ }^{14}$ Bambang Heri Supriyanto, "Penegakan Hukum Mengenai Hak Asasi Manusia (HAM) Menurut Hukum Positif di Indonesia,"Al-Azhar Indonesia Seri Pranata Sosial, 2.3 (2014), 151-68 $<$ https://jurnal.uai.ac.id/index.php/SPS/article/view/ $167 / 156>$.
}

masyarakat yang menjadi korban pelanggaran HAM Berat dimasa lalu yang belum diadili maka pemerintah bisa menggunakan asas retroaktif. Ini merupakan pilihan bagi pemerintah, apakah konsep negara hukum benar-benar dijalankan atau akan menerapkan asas retroaktif, jangan dicampur, negara hukum tetapi menggunakan asas retroaktif dan sanksi yang diterapkan menggunakan ketentuan -ketentuan dalam KUHP.

\section{DAFTAR PUSTAKA}

\section{Buku :}

\section{Astuti,Penegakan Hukum Pidana Indonesia Dalam Penyelesaian Pelanggaran Hak Asasi Manusia}

Bambang Poernomo, Asas Asas Huku Pidana, 7 ed. (Jakarta: Ghalia Indonesia, 1994)

Fenando M. Manullang, E, Legisme, legalitas dan Kepastian hukum, 2 ed. (Jakarta: KENCANA, 2017)

Hartono, Sunaryati, 1991, Politik Hukum Menuju Suatu Sistem Hukum Nasional, Bandung: Alumni

Hayat et.al, Reformasi Kebijakan Publik Perspektif Makro dan Mikro,I ed (Jakarta: Prenadamedia Group, 2018)

Jonathan Aprilino Soegijanto, "Asas Retroaktif yang Berlaku dalam Undang-Undang Peradilan HAM, LEGAL STANDING, 2. Tentang HAM (2018),

Kasim, Ifdhal, 2004,Elemen-elemen Kejahatan Dari "Crimes Against Humanity": Sebuah Penjelajahan Pustaka, Jurnal HAM, Komisi Nasional Hak Asasi Manusia, Jakarta 
Nasution, Aulia Rosa,2018, jurnal Mercatoria, Vol. 11 (1) Juni, hal 90126

Mansyhur Effendi, H.A, Hak Asasi Manusia Dalam Hukum Nasional dan Internasional, I ed (Jakarta: Ghalia Indonesia, 1994)

Soemantri M, Sri, 1992, Bunga Rampai Hukum Tata Negara Indonesia, Bandung: Penerbit Alumni

Supriyanto, "Penegakan Hukum Mengenai Hak Asasi Manusia (HAM) Menurut Hukum Positif di Indonesia.

Sri Soemantri M, 1992, Bunga Rampai Hukum Tata Negara Indonesia, Alumni, Bandung

Sirajuddin dan Winardi, Dasar Dasar Hukum Tata Negara Indonesia, (Malang Jatim: Setara Pers, 2015)

\section{Peraturan Perundang-undangan :}

Undang-Undang Dasar Negara Republik Indonesia Tahun 1945

Undang-Undang Nomor 39 Tahun 1999

Tentang Hak Asasi Manusia

Undang-Undang Nomor 26 Tahun 2000

Tentang Pengadilan Hak Asasi
Manusia Kitab Undang-Undang

Hukum Pidana

\section{Internet :}

Abdul Hakim G Nusantara. "Pelanggaran HAM Berat dan Kebijakan Nasional Untuk Penanganan dan Penyelesaiannya". Http://www.komnasham.go.id/portal/files/ AHGN-Pelanggaran_Berat_HAM_dan

Kebijkan_Nasional. Diakses tanggal 24 Februari 2010

Bagir Manan, http://www.suarakaryaonline.com/news.html=199963>, [diakses pada tanggal 12/5/2019].

Bambang Heri Supriyanto, "Penegakan Hukum Mengenai Hak Asasi Manusia (HAM) Menurut Hukum Positif di Indonesia," Al-Azhar Indonesia Seri Pranata Sosial, 2.3 (2014), 151-68 $<$ https://jurnal.uai.ac.id/index.php/SPS/arti cle/view/167/156>.

Laras Astuti,Penegakan Hukum Pidana Indonesia Dalam Penyelesaian Pelanggaran Hak Asasi Manusia, Fakultas Hukum,Univrsitas Muhammadiyah Yogyakarta Email:larasastuti@law.umy.ac.id, 2019 I476<http://doi:org/10.1017/CBO9781107 415324.004>.

Romli Atmasasmita, (2012) "Pengadilan HAM Ad Hoc", lihat, http://beritakoruptor.com/pengadilanham.html [diakses pada tanggal 1/10/2019] 